\title{
Introducción. El videoarte, utopía colectiva e historias individuales
}

\section{Ignoto, Georges}

¿Por qué haber elegido estas personas y no otras? Efectivamente, tantos especialistas, historiadores, han encontrado recientemente un interés y una pluma por aquello que habían ignorado hasta entonces que podemos legítimamente preguntarnos qué los llevó a esta decisión. A veces se dice que la historia no es otra cosa que una manera de legitimar el presente. El videoarte habrá sido la víctima más evidente de esta situación. Jean-Paul Fargier ha sido el referente del videoarte en Francia a través de sus columnas en Cahiers du Cinema. Sin él, sin sus artículos que, mes a mes, nos decían dónde estábamos, lo que se estaba creando, dónde pasaban las cosas, qué nuevo artista, qué nuevas obras aparecían, el videoarte no se habría desarrollado en Francia tal como se ha desarrollado. A través de sus artículos, a la manera de un André Bazin o de un Serge Daney, Jean-Paul Fargier ha sabido teorizar sobre las implicancias de este nuevo medio de la época. Sus análisis de las obras de Paik o Viola, como así también sus sorprendentes puntos de vista sobre obras menos conocidas constituyeron los fundamentos teóricos del videoarte. Si a esto se añade una magnífica exposición en Villeneuve-les-Avignon en 1986, sin duda la piedra angular de aquellos años-video, tendremos una mínima idea del papel desempeñado por Jean-Paul Fargier. En su texto recuerda los primeros días del video en Francia, cuando una primera generación de videastas se forjó tanto en la lucha política como en el descubrimiento de un nuevo lenguaje.

En contraste, un Richard Skryzak, más discreto, a través de los años se ha ido forjando un lugar singular en la creación video francesa. Porque se encontraba en la frontera entre Francia y Bélgica, que no tienen en absoluto la misma historia tevisual, porque que se mantiene siempre en la frontera de la pintura y el video, su experiencia ha tardado mucho tiempo en ser reconocida, pero es reflejo de esos márgenes que el video siempre ha buscado. 
Don Foresta es el otro referente de los años 70/80. Último avatar de una bella tradición franco-estadounidense hoy desaparecida pero que se remonta a la época dorada de los "americanos de París", Hemingway, Fitzgerald o Miller, Don Foresta ha sido el intermediario entre culturas antagonistas. Es en el "Centre Culturel Américain" por él dirigido que la vanguardia estadounidense ha encontrado y estimulado al público en general y a los jóvenes artistas franceses en particular. Debido a que cree profundamente en la riqueza de la colaboración y el intercambio, Don Foresta no ha cesado en su afán de relacionar artistas, científicos y técnicos. Aquí, vuelve a echar una mirada sobre el camino recorrido, sin dejar de lado los obstáculos que tuvo que enfrentar.

Gustavo Kortsarz también viene de una larga tradición, ya que desde principios del siglo XX, París no sería París sin sus argentinos. Pero más allá de eso, la experiencia del arte video ha sido durante una veintena de años la oportunidad de inventar una red de artistas y críticos que no han cesado de interconectar. Su texto, sin duda el más teórico, comienza sobre un descubrimiento asombroso: la imagen de Juan Perón en la primera obra videográfica: Sun in your Head de Wolf Vostell. ¿Azar, accidente? En las imágenes espectrales de Vostell es un fantasma que vuelve a aparecer y nos recuerda la dimensión más misteriosa, casi oculta, de la imagen electrónica.

Georges Ignoto repasa su carrera desde la universidad. Todavía es cuestión, dice, de preservar o inventar espacios de libertad, ganados con el favor de un movimiento colectivo, luchando contra el Poder, ya sea éste político o económico. Los gobiernos reaccionarios han terminado con los ideales de mayo del 68, el mercado del arte ha pasado el trapo. Pero lo más duro no es hacer que esta lucha continúe, ya que no ha dejado de existir, sino leer los nombres, conocer las responsabilidades, las lealtades y las traiciones.

Introducción. El videoarte, utopía colectiva e historias individuales fue publicado de la página 119 a página122 en Cuadernos del Centro de Estudios de Diseño y Comunicación № 52 